Article

\title{
Combined Effect of Caspase-Dependent and Caspase- Independent Apoptosis in the Anticancer Activity of Gold Complexes with Phosphine and Benzimidazole Derivatives
}

\author{
Lara Rouco ${ }^{1}$, Ángeles Sánchez-González ${ }^{2, *}$, Rebeca Alvariño ${ }^{3, *} \mathbb{1}$, Amparo Alfonso ${ }^{3}{ }^{\circledR}$, \\ Ezequiel M. Vázquez-López ${ }^{4} \mathbb{D}$, Emilia García-Martínez ${ }^{4}$ and Marcelino Maneiro ${ }^{1, *(\mathbb{D})}$ \\ 1 Departamento de Química Inorgánica, Facultade de Ciencias, Universidade de Santiago de Compostela, \\ 27002 Lugo, Spain; lara.rouco.mendez@usc.es \\ 2 Departamento de Química Inorgánica, Facultade de Farmacia, Universidade de Santiago de Compostela, \\ 15782 Santiago de Compostela, Spain \\ 3 Departamento de Farmacología, Facultade de Veterinaria, Campus Terra, \\ Universidade de Santiago de Compostela, 27002 Lugo, Spain; amparo.alfonso@usc.es \\ 4 Departamento de Química Inorgánica, Facultade de Química, Campus Universitario Lagoas-Marcosende, \\ Universidade de Vigo, 36310 Vigo, Spain; ezequiel@uvigo.es (E.M.V.-L.); emgarcia@uvigo.es (E.G.-M.) \\ * Correspondence: angeles.sanchez@usc.es (Á.S.-G.); rebeca.alvarino@usc.es (R.A.); \\ marcelino.maneiro@usc.es (M.M.); Tel.: +34-982-824-106 (M.M.)
}

\section{check for} updates

Citation: Rouco, L.; Sánchez-González, Á.; Alvariño, R.; Alfonso, A.; VázquezLópez, E.M.; García-Martínez, E.; Maneiro, M. Combined Effect of CaspaseDependent and Caspase-Independent Apoptosis in the Anticancer Activity of Gold Complexes with Phosphine and Benzimidazole Derivatives. Pharmaceuticals 2021, 14, 10. https://dx.doi.org/10.3390/ph1401 0010

Received: 24 November 2020 Accepted: 21 December 2020 Published: 24 December 2020

Publisher's Note: MDPI stays neutral with regard to jurisdictional claims in published maps and institutional affiliations.

Copyright: () 2020 by the authors. Licensee MDPI, Basel, Switzerland. This article is an open access article distributed under the terms and conditions of the Creative Commons Attribution (CC BY) license (https: / / creativecommons.org/ licenses/by/4.0/).

\begin{abstract}
Since the potential anticancer activity of auranofin was discovered, gold compounds have attracted interest with a view to developing anticancer agents that follow cytotoxic mechanisms other than cisplatin. Two benzimidazole gold(I) derivatives containing triphenylphosphine $\left(\mathrm{Au}(\mathrm{pben})\left(\mathrm{PPh}_{3}\right)\right)(\mathbf{1})$ or triethylphosphine $\left(\mathrm{Au}(\mathrm{pben})\left(\mathrm{PEt}_{3}\right)\right)(\mathbf{2})$ were prepared and characterized by standard techniques. X-ray crystal structures for $\mathbf{1}$ and $\mathbf{2}$ were solved. The cytotoxicity of $\mathbf{1}$ and $\mathbf{2}$ was tested in human neuroblastoma SH-SY5Y cells. Cells were incubated with compounds for $24 \mathrm{~h}$ with concentrations ranging from $10 \mu \mathrm{M}$ to $1 \mathrm{nM}$, and the half-maximal inhibitory concentration $\left(\mathrm{IC}_{50}\right)$ was determined. 1 and 2 showed an $\mathrm{IC}_{50}$ of 2.7 and $1.6 \mu \mathrm{M}$, respectively. In order to better understand the type of cell death induced by compounds, neuroblastoma cells were stained with Annexin-FITC and propidium iodide. The fluorescence analysis revealed that compounds were inducing apoptosis; however, pre-treatment with the caspase inhibitor Z-VAD did not reduce cell death. Analysis of compound effects on caspase-3 activity and reactive oxygen species (ROS) production in SH-SY5Y cells revealed an antiproliferative ability mediated through oxidative stress and both caspase-dependent and caspase-independent mechanisms.
\end{abstract}

Keywords: gold(I) compounds; cytotoxic activity; caspase; apoptosis; neuroblastoma SH-SY5Y

\section{Introduction}

The pharmacological use of gold compounds for the treatment of different diseases has been documented since ancient times [1,2]. More recently, in the twentieth century, the antiarthritic properties for $\mathrm{Au}(\mathrm{I})$ thiolates were observed [2], but their adverse effects led to the development of gold complexes with phosphine ligands, which are more lipophilic and remain in circulation for a longer time [3]. Auranofin, 2,3,4,6-tetra-O-acetylL-thio- $\beta$-D-glyco-pyranosato- $S$-(triethylphosphine) gold(I) is an example of these Au(I) thiolates-phosphine derivatives (see Scheme 1A), which contain a S-Au-P fragment, used as disease-modifying anti-rheumatic drugs [3-5] but also investigated for other potential therapeutic applications, from neurodegenerative disorders [6] or bacterial infections [7] to the inhibition of the novel SARS-COV-2 coronavirus [8]. 


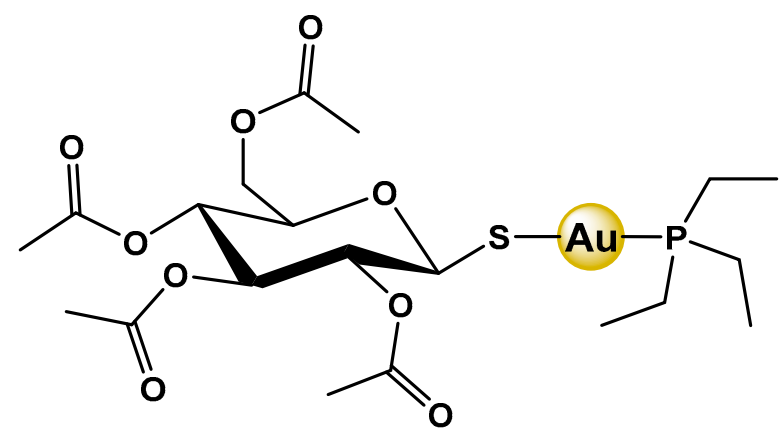

(A)

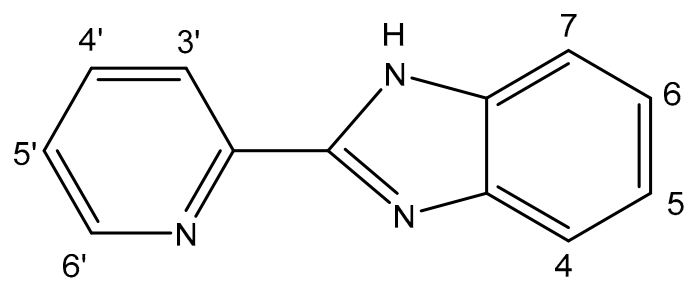

(B)

Scheme 1. (A) Auranofin: 2,3,4,6-tetra-O-acetyl-L-thio- $\beta$-D-glyco-pyranosato-S-(triethylphosphine) gold(I); (B) Numbering scheme of 2-(2'-pyridyl)benzimidazole (Hpben), which is the $\mathrm{N}$-donor ligand used in this work to coordinate gold atom instead of the S-glycoside ligand of auranofin.

The anticancer activity of this type of compound has also attracted interest due to its cytotoxic activity against cells from several tumor cell lines [9-11]. Among them, ovarian carcinoma [12], colorectal cancer [13], cervical epithelial carcinoma [14], and lung cancer cells [15]. The mechanism associated with this therapeutic activity has not yet been totally established, but results point to the ability of the $\mathrm{Au}$ (I) complexes to interact with biological targets such as proteins or nucleic acids $[16,17]$ and, particularly, with thiol-containing proteins like the thioredoxin reductase (TrxR) $[18,19]$, an enzyme involved both in the defense against oxidative damage and in the redox signaling, being relevant for cell growth and development [20]. Other studies have clearly shown the proteasome as a primary target for these complexes [21] or the inhibition of other enzymes such as glutathione reductase or peroxidase [22]. The anticancer activity of these gold compounds seems to follow different mechanisms than cisplatin or other $\mathrm{Pt}(\mathrm{II}) / \mathrm{Pd}$ (II) compounds, which mainly act by binding to DNA and inhibiting its replication. Gold compounds also exhibit cytotoxic activity against cisplatin-resistant cell lines $[9,10]$.

The increasing interest in developing different types of S-Au-P gold-based anticancer candidates led to new synthetic drugs rather than the former pyranosidic derivatives. In this sense, gold complexes incorporating ligands such as thiosemicarbazone [14,23,24], thiolate [25,26], dithiocarbamate [27], and sulfanylcarboxylates [28] have been probed to inhibit thioredoxin reductase by binding the selenocysteines or the cysteinyl thiols of the enzyme.

The replacement of the S-donor ligands by $\mathrm{N}$-donor ligands produced a new family gold complexes that have revealed interesting anticancer activities. These $\mathrm{N}$-donor ligands include imidazoles [29], naphthalimides [30], cytosines [31], bipyridines [32], phenanthrolines [33], or benzimidazoles [34-36]. The biochemical mechanism of action involved in the anticancer activity of the gold complexes with $\mathrm{N}$-donor ligands is presumably the same as that of auranofin, although it is a matter of study interest due to the diversity of results obtained in different investigations regarding biological targets for auranofin [18-22], and due to the different complex stabilization by the replacement of the thiolate ligand by the $\mathrm{N}$-donor ligand.

In the present study, we propose to use 2-(2'-pyridyl)benzimidazole (Hpben) as a ligand with potentially three N-donor atoms (see Scheme 1B), which would lead to different coordinations with the gold atom [35]. Benzimidazoles are very versatile ligands that show various pharmacological properties such as antibacterial, antiviral, and antiinflammatory $[37,38]$. Our aim is to obtain N-Au-P complexes, for which Hpben and two different phosphines are used: triphenylphosphine and triethylphosphine. Human neuroblastoma SH-SY5Y is the cell line chosen to study the cytotoxicity, the type of cell death in the anticancer activity, and the mechanism of antiproliferative action of these gold complexes. 


\section{Results}

\subsection{Analytical and Spectroscopic Characterization of $\mathbf{1}$ and $\mathbf{2}$}

Complexes 1 and $\mathbf{2}$ were obtained in high yield as detailed in the experimental section (Scheme 2). Their structures were fully characterized using ${ }^{1} \mathrm{H},{ }^{13} \mathrm{C}$ and ${ }^{31} \mathrm{P} \mathrm{NMR}$ spectroscopy, IR and UV spectroscopy, electrospray ionization mass spectroscopy (ESIMS), and single-crystal X-ray crystallography. Elemental analyses establish a formula $\left(\mathrm{Au}\right.$ (pben) $\left.\left(\mathrm{PR}_{3}\right)\right)$, being $\mathrm{R}=\mathrm{Ph}$ for 1 and $\mathrm{R}=\mathrm{Et}$ for 2 . ESI-MS spectra confirmed these formulas for the neutral complexes by showing molecular ion peaks at $m / z 644.14$ for 1 and $m / z 510.13$ for 2 (Figures S1 and S2). UV-Vis spectra showed in DMSO a common absorption band at $313 \mathrm{~nm}$ assigned to $\pi-\pi^{*}$ transitions located in the heteroaromatic benzimidazole rings (Figures S3 and S4). Complex 1 displays an additional band at 325 $\mathrm{nm}$, which has also previously been found in gold(I) complexes containing the ancillary $\mathrm{PPh}_{3}$ ligand [34].

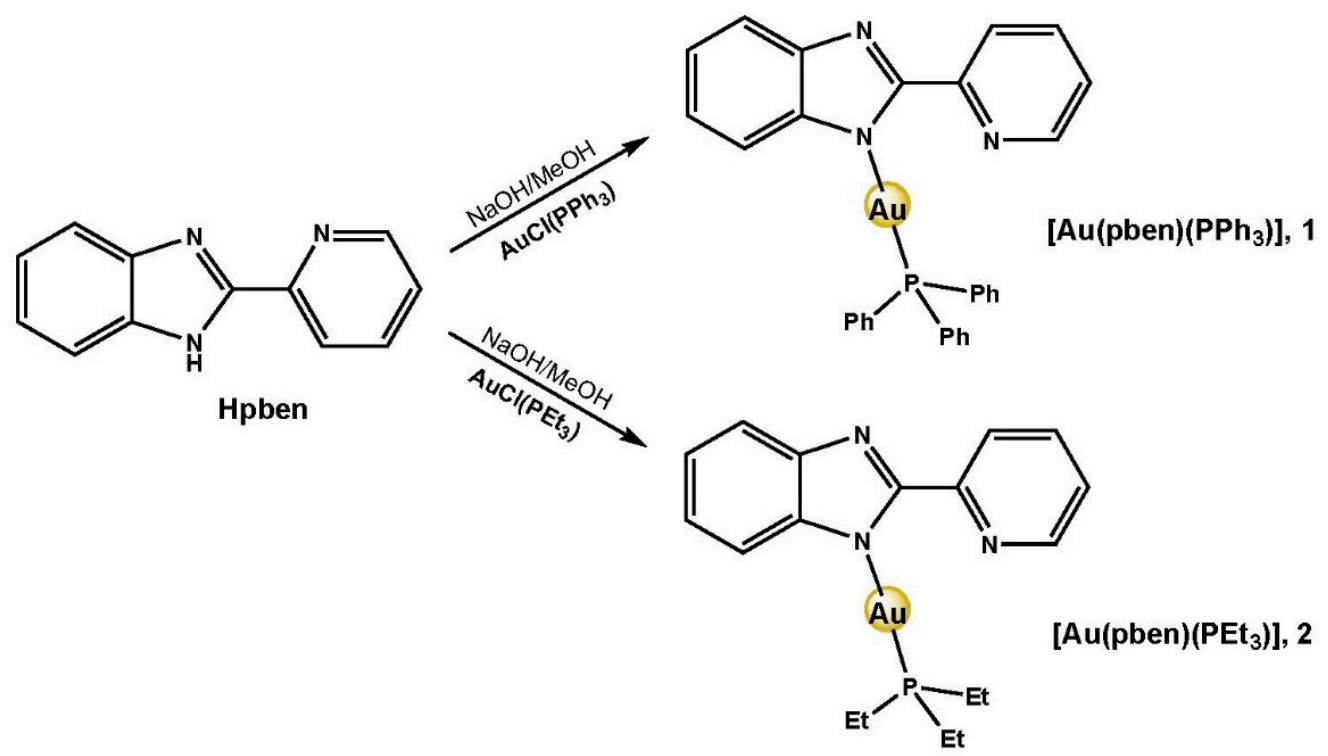

Scheme 2. Synthesis of complexes 1 and 2.

The IR spectra of these complexes (Figures S5 and S6), when compared with the corresponding spectrum of its free ligand, show the absence of the $v(\mathrm{~N}-\mathrm{H})$ band, which is present in the spectrum of the Hbpen between $2990-2700 \mathrm{~cm}^{-1}$, consistent with the deprotonation of this group and the $\mathrm{N}$-coordination to the Au atom. In both complexes, the aromatic tension bands of the pben ligand do not undergo significant changes when coordination occurs, although rigorous assignment is made difficult by the great intensity showed by the bands from the phosphines.

The ${ }^{1} \mathrm{H}$ NMR spectra of $\mathbf{1}$ and $\mathbf{2}$ showed each one as well-resolved set of signals (Figures S7 and S8); the $\mathrm{H6}^{\prime}$ proton at $\delta 8.57 / 8.52$ was the most deshielded and downfield shifted of $0.13-0.18 \mathrm{ppm}$ with respect to the free ligand $\left({ }^{1} \mathrm{H}\right.$ NMR and ${ }^{13} \mathrm{C}$ NMR spectra for free ligand are collected in Figures S9-S12), while the resonance of the H3' proton was shifted at about $0.18 \mathrm{ppm}$, which suggests some involvement of the pyridinic nitrogen in the Au-pben bonding. In both complexes, the $\mathrm{N}-\mathrm{H}$ signal of the free ligand disappeared, confirming the deprotonation of Hbpen. In the spectrum of $\mathbf{1}$, the signals corresponding to the co-ligand $\mathrm{PPh}_{3}$ overlap with those of $\mathrm{pben}^{-}$, so the assignment is tentative. Aromatic carbons from pben ${ }^{-}$and triphenylphosphine ligands are registered in the ${ }^{13} \mathrm{C}$ NMR spectrum of $\mathbf{1}$ (Figure S13). ${ }^{31} \mathrm{P}$ NMR spectrum of $\mathbf{1}$ shows a single signal at $30.9 \mathrm{ppm}$, which is evidence that the gold complex is not altered in solution (Figure S14). In the case of 2, the identification and assignment of $\mathrm{PEt}_{3}$ signals were unambiguous with the $-\mathrm{CH}_{3}$ signals as a doublet of triplets at $1.31 \mathrm{ppm}$ due to the coupling with ${ }^{31} \mathrm{P}$ (coupling constant ${ }^{3} \mathrm{~J}(\mathrm{H}-\mathrm{P}$ ) 
$=18.5 \mathrm{~Hz}$, slightly higher than the corresponding to the free $\left.\mathrm{PEt}_{3}, 14 \mathrm{~Hz}\right)$. The ${ }^{13} \mathrm{C} \mathrm{NMR}$ spectrum of 2 showed two signals (Figure S15) corresponding to the phosphine at $9.2\left(\mathrm{CH}_{3}\right)$ and $18.5\left(\mathrm{~d}, \mathrm{CH}_{2}, J(\mathrm{C}-\mathrm{P})=37.3 \mathrm{~Hz}\right) \mathrm{ppm}, \delta$ and $\mathrm{J}$ values which are like those found for other $\mathrm{Au}(\mathrm{I})-\mathrm{PEt}_{3}$ complexes $[14,28]$, and that contrast with the values of non-coordinated $\mathrm{PEt}_{3} .{ }^{31} \mathrm{P}$ NMR spectrum of 2 showed a single signal at $26.9 \mathrm{ppm}$ (Figure S16).

The electrochemical behavior of compounds $\mathbf{1}, \mathbf{2}$ was investigated in DMSO- tetraethylammonium perchlorate $0.1 \mathrm{M}$ solvent system through cyclic voltammetry. Figure 1 shows the voltammograms at different scan rates. The $\mathrm{Au}(\mathrm{I})$ gold complexes undergo one oxidation process (at -0.594 for $\mathbf{1}$ and at $-0.597 \mathrm{~V}$ for 2 ) to form the $\mathrm{Au}(\mathrm{III})$ species.

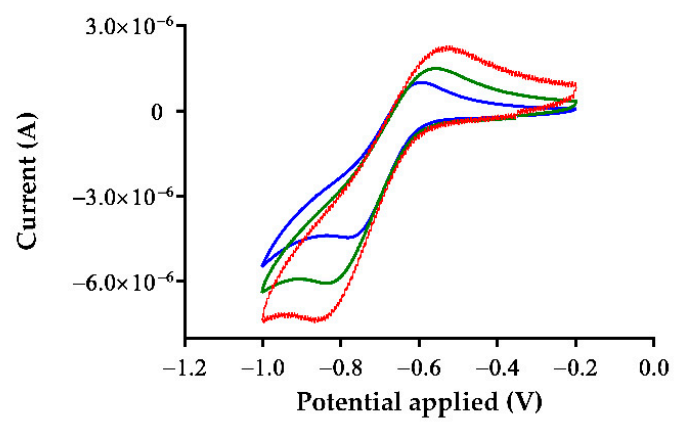

(A)

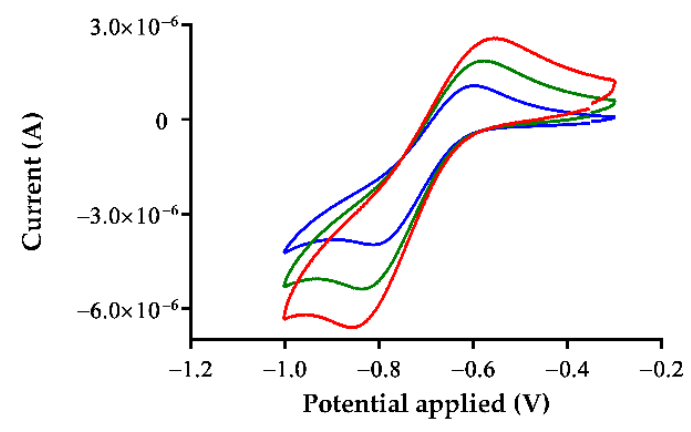

(B)

Figure 1. Cyclic voltammograms for (A) 1 and (B) 2 at different scan rates: $0.02 \mathrm{~V} \mathrm{~s}^{-1}$ (blue), $0.05 \mathrm{~V} \mathrm{~s}^{-1}$ (green) and $0.09 \mathrm{~V} \mathrm{~s}^{-1}$ (red).

The redox properties of the two gold(I) complexes showed grossly similar behavior consisting of a quasi-reversible $\mathrm{Au}(\mathrm{I}) / \mathrm{Au}(\mathrm{III})$ oxidation. The criteria of reversibility were checked by observing the constancy of peak-peak separation $\left(\Delta \mathrm{E}_{\mathrm{p}}=\mathrm{E}_{\mathrm{pa}}-\mathrm{E}_{\mathrm{pc}}\right)$ of $188 \mathrm{mV}$ for $\mathbf{1}$ and $214 \mathrm{mV}$ for $\mathbf{2}$ at $0.02 \mathrm{~V} \mathrm{~s}^{-1}$. The reversible character decreased as scan rates increased. Thus, $\Delta \mathrm{E}_{\mathrm{p}}$ are $281 \mathrm{mV}$ for $\mathbf{1}$ and $259 \mathrm{mV}$ for 2 at $0.05 \mathrm{~V} \mathrm{~s}^{-1}$, and even $344 \mathrm{mV}$ for $\mathbf{1}$ and $297 \mathrm{mV}$ for $\mathbf{2}$ at $0.09 \mathrm{~V} \mathrm{~s}^{-1}$. As is predictable, the intensity of the current also increased at higher scan rates. Cyclic voltammograms of $\mathbf{1}, \mathbf{2}$ endorse the purity and stability of both complexes in solution.

\subsection{Crystal Structures of Complexes $\mathbf{1}$ and $\mathbf{2}$}

Single crystals of complex 1 suitable for X-ray diffraction studies were obtained by slow evaporation of the methanolic solution at room temperature. The molecular structure is shown in Figure 2 and Figure S17, and the main bond distances and angles are shown in Table 1. 


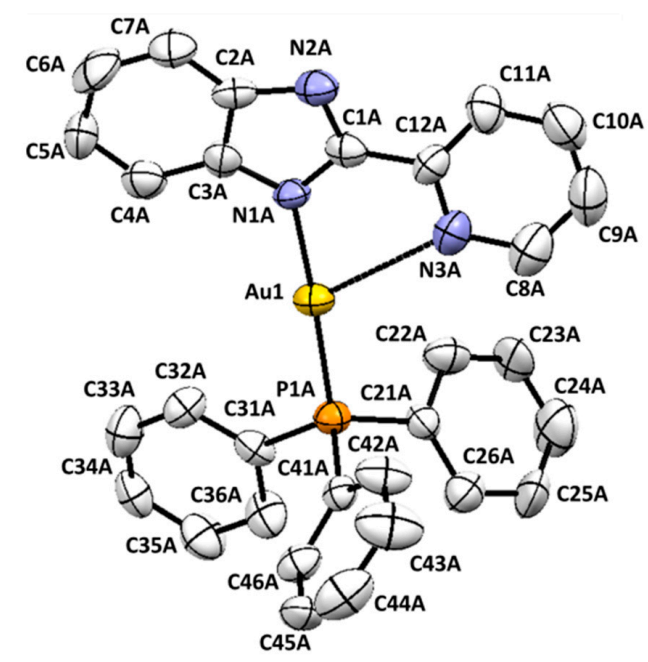

Figure 2. ORTEP representation of one of the molecules presents in the crystal structure of compound 1 (hydrogen atoms have been omitted for clarity).

Table 1. Selected bond lengths $(\AA)$ and angles $\left(^{\circ}\right)$ for $\mathbf{1}$.

\begin{tabular}{cccc}
\hline Bond & Lengths (̊̊) & Bond & Angles ( $\left.{ }^{\circ}\right)$ \\
\hline $\mathrm{Au}(1)-\mathrm{N}(1)$ & $2.058(6)$ & $\mathrm{Au}(2)-\mathrm{N}(4)$ & $2.060(6)$ \\
$\mathrm{Au}(1)-\mathrm{P}(1)$ & $2.230(2)$ & $\mathrm{Au}(2)-\mathrm{P}(2)$ & $2.235(2)$ \\
$\mathrm{Au}(1) \cdots \mathrm{N}(3)$ & $2.792(7)$ & $\mathrm{Au}(2) \cdots \mathrm{N}(6)$ & $2.782(7)$ \\
$\mathrm{N}(1)-\mathrm{Au}(1)-\mathrm{P}(1)$ & $176.40(18)$ & $\mathrm{N}(4)-\mathrm{Au}(2)-\mathrm{P}(2)$ & $174.75(18)$ \\
$\mathrm{N}(1)-\mathrm{Au}(1)-\mathrm{N}(3)$ & $68.5(2)$ & $\mathrm{N}(4)-\mathrm{Au}(2)-\mathrm{N}(6)$ & $68.8(2)$ \\
$\mathrm{P}(1)-\mathrm{Au}(1)-\mathrm{N}(3)$ & $113.52(17)$ & $\mathrm{P}(2)-\mathrm{Au}(2)-\mathrm{N}(6)$ & $114.48(16)$ \\
$\mathrm{C}(13)-\mathrm{P}(1)-\mathrm{Au}(1)$ & $110.5(3)$ & $\mathrm{C}(43)-\mathrm{P}(2)-\mathrm{Au}(2)$ & $113.9(3)$ \\
$\mathrm{C}(25)-\mathrm{P}(1)-\mathrm{Au}(1)$ & $115.1(3)$ & $\mathrm{C}(49)-\mathrm{P}(2)-\mathrm{Au}(2)$ & $108.0(3)$ \\
$\mathrm{C}(19)-\mathrm{P}(1)-\mathrm{Au}(1)$ & $112.9(3)$ & $\mathrm{C}(55)-\mathrm{P}(2)-\mathrm{Au}(2)$ & $114.9(3)$ \\
$\mathrm{C}(3)-\mathrm{N}(1)-\mathrm{Au}(1)$ & $129.6(6)$ & $\mathrm{C}(31)-\mathrm{N}(4)-\mathrm{Au}(2)$ & $126.3(5)$ \\
$\mathrm{C}(1)-\mathrm{N}(1)-\mathrm{Au}(1)$ & $125.5(5)$ & $\mathrm{C}(33)-\mathrm{N}(4)-\mathrm{Au}(2)$ & $128.7(5)$ \\
$\mathrm{C}(8)-\mathrm{N}(3)-\mathrm{Au}(1)$ & $106.2(5)$ & $\mathrm{C}(38)-\mathrm{N}(6)-\mathrm{Au}(2)$ & $104.7(5)$ \\
$\mathrm{C}(9)-\mathrm{N}(3)-\mathrm{Au}(1)$ & $134.2(7)$ & $\mathrm{C}(39)-\mathrm{N}(6)-\mathrm{Au}(2)$ & $135.3(6)$ \\
\hline
\end{tabular}

The asymmetric unit contained two molecules of $\mathbf{1},\left(\mathrm{Au}(\mathrm{pben}) \mathrm{PPh}_{3}\right)$, with slightly different bond distances and angles values and one disordered methanol molecule. Since it did not establish any relevant interaction with $\left(\mathrm{Au}(\mathrm{pben}) \mathrm{PPh}_{3}\right)$, it was removed using the SQUEEZE program [39]. In the two molecules of the complex, the metal ion is coordinated to the phosphorous atom of triphenylphosphine and to the nitrogen atom of the benzimidazolate ring with an almost linear disposition. An additional contact was established between the nitrogen atom of the pyridine and the gold ion, giving rise to a $2+1$ coordination number.

The Au-P Bond lengths (2.230(2) y 2.235(2) $\AA$ ) were similar to those found in the cationic complex $\left(\mathrm{Au}(\mathrm{Hpben})\left(\mathrm{PPh}_{3}\right)\right) \mathrm{ClO}_{4}[40]$. However, the $\mathrm{Au}-\mathrm{N}$ bond distances $(2.058(6)$ and 2.060(6)) were slightly shorter than those found in the $\left(\mathrm{Au}(\mathrm{Hpben})\left(\mathrm{PPh}_{3}\right)\right)^{+}$cation (2.075(4) $\AA$ )), consistent with a stronger interaction between the metal ion and the deprotonated ligand. The bond length between the gold and the pyridine nitrogen $(\mathrm{Au}(1) \cdots$ $\mathrm{N}(3)=2.729(7) \AA$ and $\mathrm{Au}(2) \cdots \mathrm{N}(6)=2.782(7) \AA$ ) was shorter than the sum of the Van der Waals radii $(3.25 \AA)$, and shorter than that observed in $\left(\mathrm{Au}(\mathrm{Hpben})\left(\mathrm{PPh}_{3}\right)\right) \mathrm{ClO}_{4}$ $(2.930 \AA)[40]$. Bond lengths and angles found in the triphenylphosphine ligands (not collected in Table 2) showed normal values and similar to those reported for complexes of $\mathrm{Au}(\mathrm{I})$ and $\mathrm{PPh}_{3}[40-42]$. 
Table 2. Selected bond lengths $(\AA)$ and angles $\left(^{\circ}\right)$ for 2 .

\begin{tabular}{cccc}
\hline Bond & Lengths $(\AA)$ & Bond & Angles $\left(^{\circ}\right.$ ) \\
\hline $\mathrm{Au}(1)-\mathrm{N}(1)$ & $2.050(6)$ & $\mathrm{Au}(2)-\mathrm{N}(4)$ & $2.058(5)$ \\
$\mathrm{Au}(1)-\mathrm{P}(1)$ & $2.2288(18)$ & $\mathrm{Au}(2)-\mathrm{P}(2)$ & $2.224(2)$ \\
$\mathrm{Au}(1) \cdots \mathrm{N}(3)$ & $2.975(6)$ & $\mathrm{Au}(2) \cdots \mathrm{N}(6)$ & $2.849(6)$ \\
$\mathrm{N}(1)-\mathrm{Au}(1)-\mathrm{P}(1)$ & $172.59(16)$ & $\mathrm{N}(4)-\mathrm{Au}(2)-\mathrm{P}(2)$ & $174.37(17)$ \\
$\mathrm{N}(1)-\mathrm{Au}(1)-\mathrm{N}(3)$ & $66.34(19)$ & $\mathrm{N}(4)-\mathrm{Au}(2)-\mathrm{N}(6)$ & $67.38(19)$ \\
$\mathrm{P}(1)-\mathrm{Au}(1)-\mathrm{N}(3)$ & $120.75(12)$ & $\mathrm{P}(2)-\mathrm{Au}(2)-\mathrm{N}(6)$ & $116.88(13)$ \\
\hline
\end{tabular}

Single crystals of 2 were obtained as detailed in the experimental section; a perspective view is shown in Figure 3 and Figure S18, and selected bond parameters are collected in Table 2. The asymmetric unit of the crystal structure of $\mathbf{2}$ also consists of two chemically equivalent molecules in which the benzimidazolate unit is acting as a monodentate ligand through the N(1) nitrogen atom. The gold(I) ion was also arranged in the usual almost linear coordination geometry, coordinated to pben and to the phosphorous atom of triethylphosphine. In the same way as in $\mathbf{1}$, an additional contact was established between the nitrogen atom of the pyridine and the gold ion, giving rise to a $2+1$ coordination number. Au-P Bond lengths (2.2288(18) and 2.224(2) $\AA$ ) and Au-N bond distances (2.050(6) and 2.058(5)) are values very close to those found in $\mathbf{1}$.

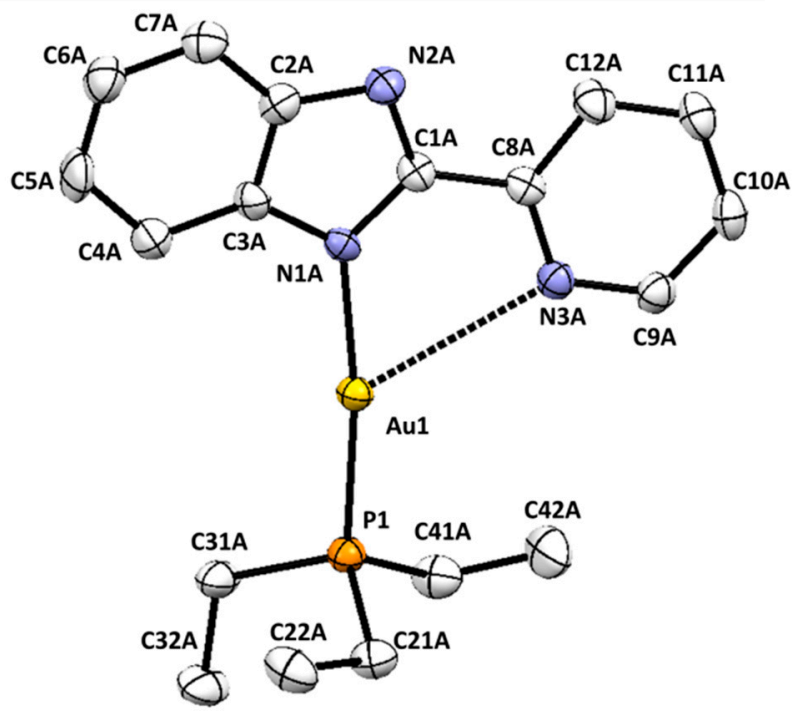

Figure 3. ORTEP representation of one of the molecules presents in the crystal structure of compound 2 (hydrogen atoms have been omitted for clarity).

\subsection{Cytotoxicity Studies and Determination of Cell Death Type}

SH-SY5Y neuroblastoma cells were used to study the toxic effect of the $\mathrm{Au}(\mathrm{I}) \mathrm{com}$ plexes. Cells were treated with different concentrations of $\mathbf{1}$ and $\mathbf{2}$ at two incubation times, 6 and $24 \mathrm{~h}$. Table 3 shows $\mathrm{IC}_{50}$ values calculated for compounds (see also Figure S19). Complex 2 was more cytotoxic, presenting lower $\mathrm{IC}_{50}$ values than complex $\mathbf{1}$ at both times. 
Table 3. $\mathrm{IC}_{50}(\mu \mathrm{M})$ of gold compounds in SH-SY5Y cells determined with a 3-(4,5-dimethyl thiazol2-yl)-2,5-diphenyl tetrazolium bromide (MTT) assay. IC $_{50}$ (half maximal inhibitory concentration), $R^{2}$ (coefficient of determination which gives the goodness-of-fit for the regression model).

\begin{tabular}{ccccc}
\hline Compound & Incubation Time (h) & $\mathbf{I C}_{\mathbf{5 0}}(\boldsymbol{\mu M})$ & $\boldsymbol{R}^{\mathbf{2}}$ & $\mathbf{9 5 \%}$ Confidence Interval \\
\hline $\mathbf{1}$ & 6 & 6.2 & 0.97 & 3.851 to 8.30 \\
& 24 & 2.7 & 0.94 & 1.534 to 4.684 \\
$\mathbf{2}$ & 6 & 3.1 & 0.93 & 1.340 to 5.015 \\
& 24 & 1.6 & 0.91 & 0.8094 to 3.018 \\
\hline
\end{tabular}

Next, to determine the type of cell death produced by gold complexes, their effects on neuroblastoma cells were evaluated using the fluorescent dyes Annexin V-FITC (fluorescein isothiocyanate) and propidium iodide (PI), which allow the detection of necrotic and apoptotic cell populations by flow cytometry. Three populations were discriminated: viable cells (Annexin V-FITC and PI negative cells), apoptotic cells (including Annexin VFITC positive and PI negative cells, and Annexin V-FITC and PI-positive cells), and necrotic cells (Annexin V-FITC negative and PI-positive cells). In this assay, SH-SY5Y cells were treated with compounds at $\mathrm{IC}_{50}$ concentrations for 6 and $24 \mathrm{~h}$. Furthermore, to check if the complexes 1 and $\mathbf{2}$ were inducing caspase-dependent apoptosis, cells were preincubated with the pan-caspase inhibitor Z-VAD-FMK (carbobenzoxy-valyl-alanyl-aspartyl[O-methyl]-fluoromethylketone) at $40 \mu \mathrm{M}$ for $24 \mathrm{~h}$, followed by treatment with compounds at $\mathrm{IC}_{50}$ concentrations for 6 and $24 \mathrm{~h}$. In order to validate the model, staurosporine (STS) was used as cell death control (Figure 4). 

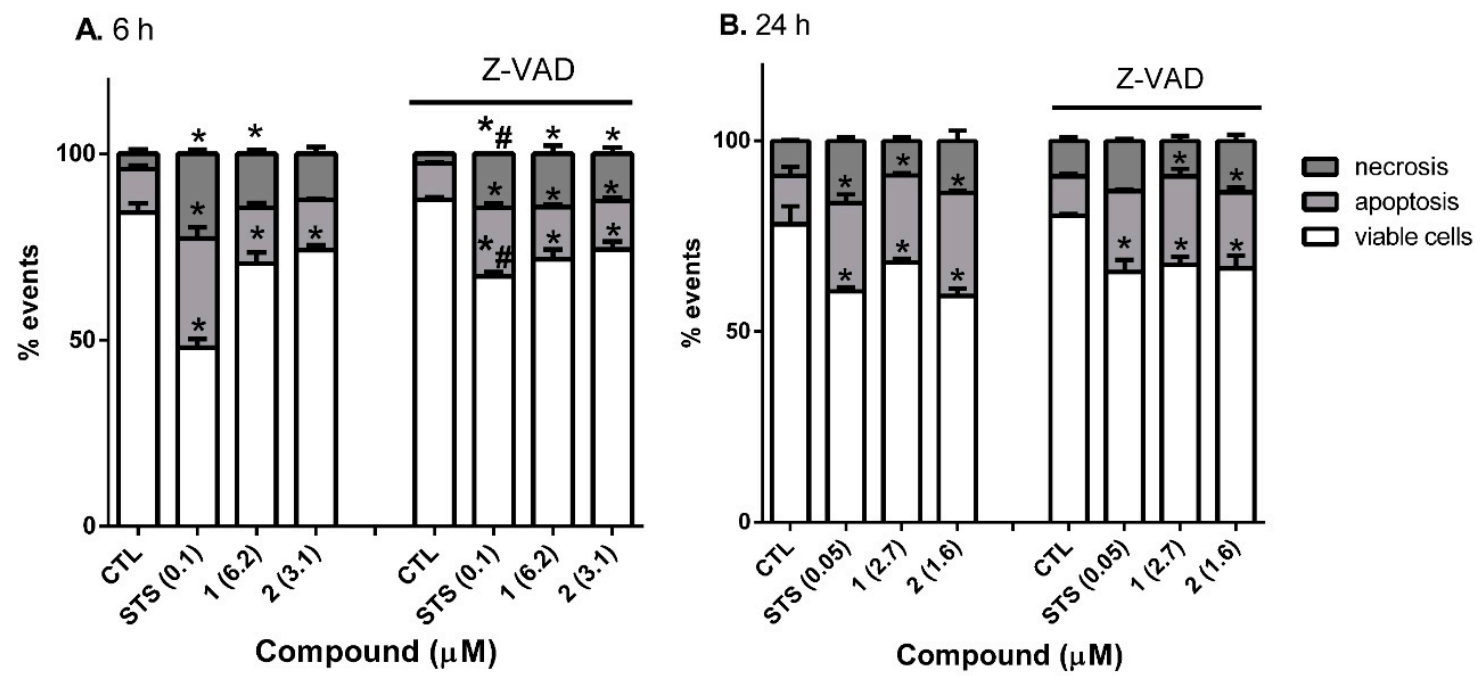

Figure 4. Determination of cell death type produced by $\mathbf{1}$ and $\mathbf{2}$ on SH-SY5Y cells. Human neuroblastoma cells were treated with compounds for 6 (A) and $24 \mathrm{~h}$ (B) with and without pre-incubation with $40 \mu \mathrm{M}$ Z-VAD. Staurosporine (STS) was used as a positive control. Cell death type was determined with Annexin V-FITC/PI staining by flow cytometry. Values are mean \pm SEM of three independent replicates expressed as a percentage of untreated control cells. Statistical differences were determined by Student's $t$ test. ${ }^{*} p<0.05$, comparison of compound treatment and control cells. \# $p<0.05$, comparison between treatments with compounds alone and co-treatment with compounds and Z-VAD.

Treatment with compounds $\mathbf{1}$ and $\mathbf{2}$ for $6 \mathrm{~h}$ produced a significant decrease in viable cells, with levels of $70.6 \pm 3.0 \%$ and $74.1 \pm 1.4 \%$, respectively $(p<0.05)$ (Figure $4 \mathrm{~A}$ ). In this assay, gold compounds produced a lower decrease in cell viability than expected, which could be due to the differences between the 3-(4,5-dimethyl thiazol-2-yl)-2,5-diphenyl tetrazolium bromide (MTT) assay and Annexin/PI staining. IC 50 values were determined with MTT, which quantifies cell viability based on mitochondrial activity, so it was more sensitive than the Annexin/PI staining, which detects changes in the plasmatic membrane [43-45]. Both complexes produced an increase in apoptotic cells $(15.0 \pm 1.2 \%$ for $\mathbf{1}$ and $13.7 \pm 1.3 \%$ for $\mathbf{2}$ ). Moreover, compound $\mathbf{1}$ significantly augmented necrotic cells $(14.4 \pm 1.0 \%)$ compared to control cells. As expected, the addition of $0.1 \mu \mathrm{M}$ STS, a known apoptotic inducer, generated an increase of apoptotic cells $(29.3 \pm 3.1 \%)$.

On the other hand, cells co-treated with Z-VAD and compounds 1 and 2 for $6 \mathrm{~h}$ presented a significant decrease in viable cells $(71.6 \pm 2.7 \%$ and $74.3 \pm 2.1 \%$, respectively). Interestingly, the percentages of apoptotic cells after pre-treatment with Z-VAD $(14.1 \pm 0.7 \%$ and $13.0 \pm 0.9 \%$, respectively) were similar to those obtained with the compounds alone. Otherwise, the apoptotic death produced by $0.1 \mu \mathrm{M}$ STS alone was significantly reduced when neuroblastoma cells were pre-treated with the caspase inhibitor $(18.5 \pm 1.1 \%, p<0.05)$. Regarding necrosis, its levels were comparable to those observed with gold complexes alone, with percentages among $12.7-14.3 \%$. In the case of STS, necrotic cells were significantly reduced by pre-treatment with Z-VAD. The results obtained with STS validated the model since its cytotoxic effects were reduced when the caspase inhibitor was added to SH-SY5Y cells. However, Z-VAD was unable to reduce the cell death produced by gold compounds.

This assay was repeated after a longer incubation time, $24 \mathrm{~h}$ (Figure 4B). A reduction in cell survival was observed when cells were treated with complexes $\mathbf{1}$ and $\mathbf{2}(68.1 \pm 0.9 \%$ and $59.3 \pm 2.0 \%$, respectively). Once again, compounds produced a significant augmentation of apoptotic cells, with levels of $22.8 \pm 0.6 \%$ after the addition of complex 1, and $27.0 \pm 0.5 \%$ when cells were treated with 2 . In order to further confirm the results obtained at $6 \mathrm{~h}$, neuroblastoma cells were pre-treated with $40 \mu \mathrm{M}$ Z-VAD, followed by the addition of complexes $\mathbf{1}$ and $\mathbf{2}$ for $24 \mathrm{~h}$. In this assay, both compounds produced a significant decrease in viable cells $(67.5 \pm 2.1 \%$ and $66.2 \pm 3.3 \%$, respectively). In addition, the levels of 
apoptotic cells were between 19.9-23.2\%, confirming the inability of Z-VAD to inhibit the death of neuroblastoma cells. With respect to STS, pre-treatment with Z-VAD did not produce a significant reduction in the apoptotic death generated by the compound after $24 \mathrm{~h}$. This effect has been previously described and is related to the ability of STS to produce caspase-dependent and caspase-independent apoptosis. The first one happens at shorter incubation times, whilst the second one occurs more slowly and can be observed at longer incubation times $[46,47]$. In our model, Z-VAD reduced the apoptosis produced by STS after $6 \mathrm{~h}$ of incubation, but no effect was found at $24 \mathrm{~h}$, agreeing with these previous results.

In the case of gold complexes, previous studies have reported that this class of compounds can also induce apoptosis through both caspase-dependent and caspaseindependent mechanisms [48,49]. In this context, the effect of complexes $\mathbf{1}$ and $\mathbf{2}$ on caspase-3 activity was analyzed. SH-SY5Y cells were treated with compounds at $\mathrm{IC}_{50}$ concentrations for 6 and $24 \mathrm{~h}$, and the enzymatic activity was determined (Figure 5).

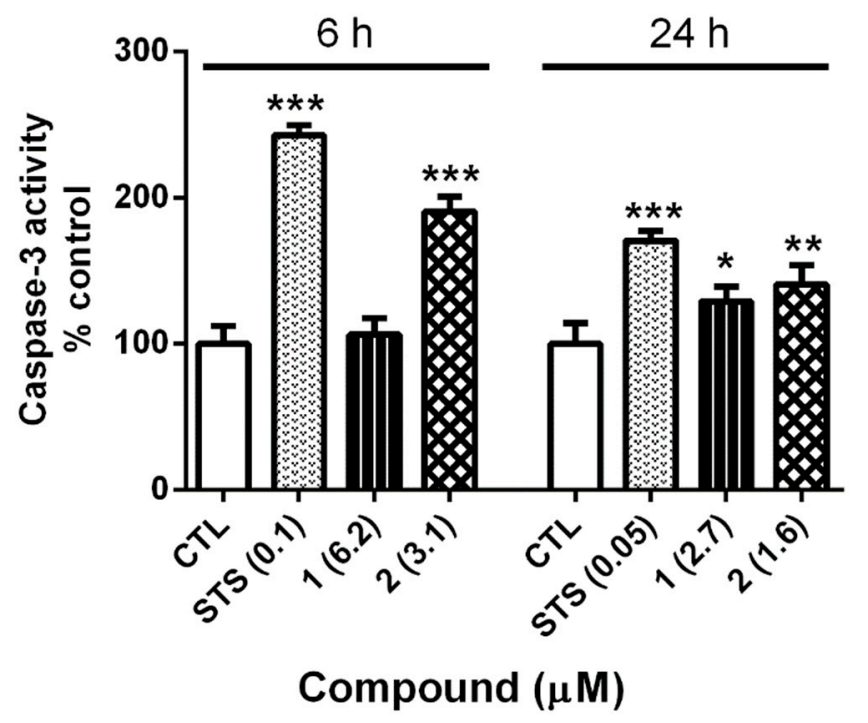

Figure 5. Caspase-3 activity in human neuroblastoma cells treated with gold compounds $\mathbf{1}$ and $\mathbf{2}$. Compounds were added to the cells for $6 \mathrm{~h}$ and $24 \mathrm{~h}$. STS was used as a positive control. Data are mean \pm SEM of three experiments performed in triplicate, expressed as a percentage of control cells, and compared control cells by Student's $t$ test. ${ }^{*} p<0.05,{ }^{* *} p<0.01,{ }^{* * *} p<0.001$.

At $6 \mathrm{~h}$, STS produced an augmentation in caspase-3 activity of $242.5 \pm 7.2 \%(p<0.001)$, agreeing with its previously reported effect on caspase-dependent apoptosis at short incubation times [46,47]. With regard to gold complexes, only 2 showed a significant increase in enzyme activity $(190 \pm 10.3 \% ; p<0.001)$. The assay was repeated for $24 \mathrm{~h}$ and both complexes augmented caspase- 3 activity, $129.0 \pm 10.5 \%(p<0.05)$ and $140.8 \pm 12.3 \%$ $(p<0.01)$, respectively. At this time, STS also produced a significant increase in caspase- 3 activity $(170.5 \pm 6.8 \%, p<0.001)$. This rise was smaller than the observed at $6 \mathrm{~h}$, confirming that the involvement of caspase-3 in STS-induced death is lesser at $24 \mathrm{~h}$. With regard to gold complexes, compound 2 presented a similar behavior to STS, with a lower increase in caspase- 3 activity at $24 \mathrm{~h}$, whereas complex 1 produced a slight augmentation of caspase- 3 activity. These results could explain the lack of effect of pre-treatment with Z-VAD in our previous assays, pointing to a combined effect of the compound on caspase-dependent and caspase-independent apoptosis.

Previously published studies [48,49] stated that $\mathrm{Au}(\mathrm{I})$ and $\mathrm{Au}(\mathrm{III})$ complexes produce cell death through the induction of oxidative stress. Therefore, the effect of compounds on ROS production was analyzed. Cells were co-treated with $\mathbf{1}$ and $\mathbf{2}$ at nine concentrations (0.01-10 $\mu \mathrm{M})$ for $24 \mathrm{~h}$, and the levels of these damaging molecules were evaluated with a fluorometric assay (Figure 6). Treatment with complex 1 significantly augmented ROS 
production, reaching levels of $122.4 \pm 11.9 \%(p<0.05)$ at $5 \mu \mathrm{M}$ compared to control cells. Compound 2 also produced a significant increase in ROS release at three concentrations $(0.01,0.5$, and $7.5 \mu \mathrm{M})$, being the greater augmentation at $7.5 \mu \mathrm{M}(129.7 \pm 13.8 \%, p<0.05)$. The increase generated by gold complexes was comparable to the rise produced by the known pro-oxidant tert-butyl hydroperoxide (TBHP) at $75 \mu \mathrm{M}(134.9 \pm 7.1 \%, p<0.001)$.

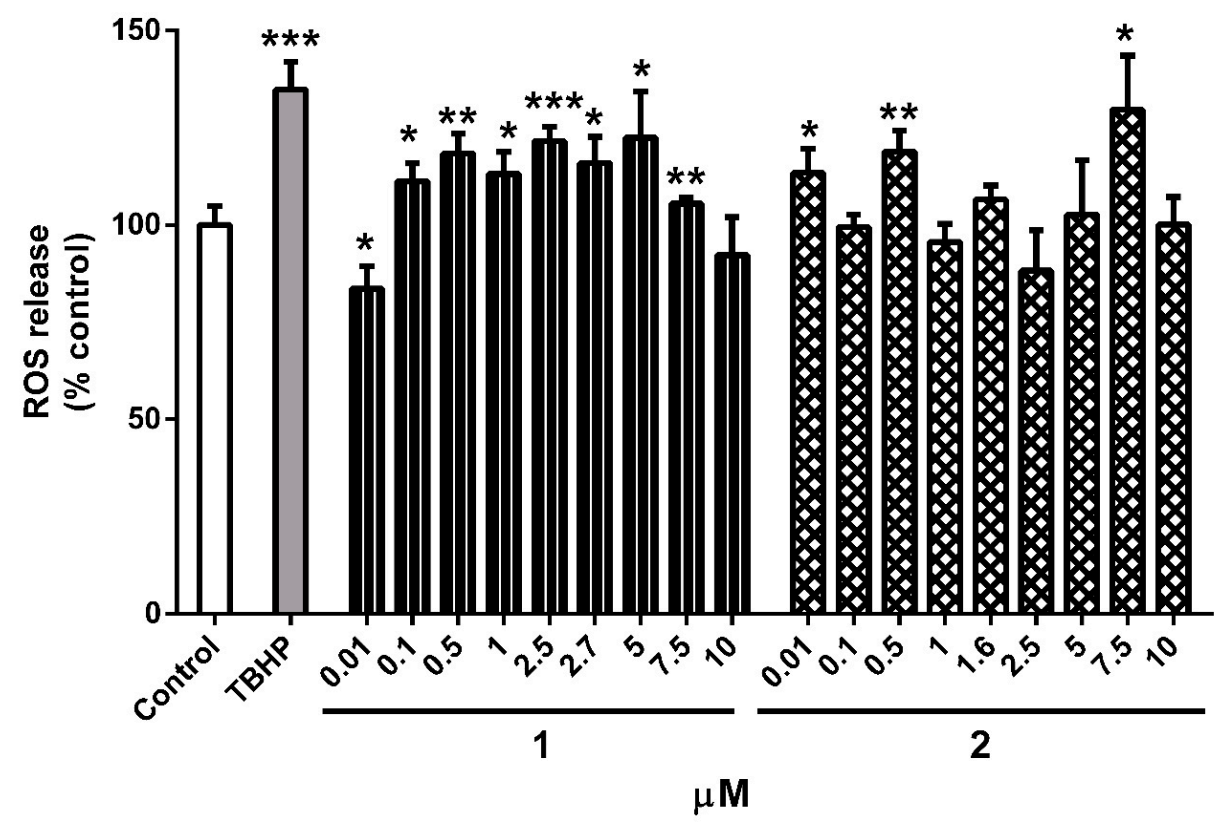

Figure 6. Effect of 1 and 2 on ROS levels in human neuroblastoma cells. Compounds (0.01-10 $\mu \mathrm{M})$ were added to the cells for $24 \mathrm{~h}$. The fluorescent dye carboxy- $\mathrm{H}_{2}$ DCFDA was used to evaluate reactive oxygen species (ROS) production. tert-butyl hydroperoxide (TBHP) at $75 \mu \mathrm{M}$ was used as a positive control. Mean \pm SEM of three independent experiments. Data are expressed as a percentage of control cells. Statistical differences between treatments and control cells were determined with Student's $t$ test. ${ }^{*} p<0.05,{ }^{* *} p<0.01,{ }^{* * *} p<0.001$.

\section{Discussion}

The set of techniques used to characterize $\mathbf{1}$ and $\mathbf{2}$ both in solid-state and in solution has made it possible to establish the high purity of both compounds and their stability in solution. Structural characterization did not allow the differentiation of any property between compounds that caused a difference in cytotoxicity. However, complex 2, which incorporates triethylphosphine co-ligand, shows more cytotoxicity than $\mathbf{1}$, with a triphenylphosphine co-ligand. The same influence of substitution of $\mathrm{PPh}_{3}$ for $\mathrm{PEt}_{3}$ on cytotoxicity has been already reported before for mono phosphinegold(I) sulfanylcarboxylates [28].

Different electrochemical properties have been reported for other anticancer gold complexes [34-36], but, in the present case, the electrochemical behavior of $\mathbf{1}$ and $\mathbf{2}$ is basically similar, according to both their redox potential values and their quasi-reversible character, so we can conclude that this should not be the factor that determines the different toxicity of both compounds. The greatest steric effect of the triphenyl substituents on phosphine in $\mathbf{1}$ with respect to the triethyl substituents in $\mathbf{2}$ arises as a possible explanatory factor that would explain the different antiproliferative action of these gold complexes.

One of the main interest in anticancer gold complexes is the development of pharmacological candidates with cytotoxic activity against cells from tumor lines which are resistant to the chemotherapeutic drug cisplatin or new drugs that may induce apoptosis in cancer cells through different mechanisms than cisplatin or other $\mathrm{Pt}(\mathrm{II}) / \mathrm{Pd}(\mathrm{II})$ compounds $[9,10]$. The cytotoxicity of cisplatin and oxaliplatin have been previously reported on the human neuroblastoma cell line SH-SY5Y [50]. IC $_{50}$ values for these platinum compounds of $15-50 \mu \mathrm{M}$ using the MTT assay at an incubation time of $24 \mathrm{~h}$ are significantly higher 
than values obtained for gold(I) complexes 1 and $\mathbf{2}$ (IC50 of 1.6-2.7 $\mu \mathrm{M}$ ), which behaved as more cytotoxic.

In the case of the cisplatin derivatives, their cytotoxic activity has been linked to their ability to crosslink with the purine bases on the DNA. In the present study, the results obtained in the caspase- 3 assay and in the determination of ROS production indicate that gold complexes could have antitumor behavior, being able to induce apoptotic cell death through the increase of ROS levels. The redox potentials of $\mathbf{1}$ and $\mathbf{2}$ are outside the biologically accessible redox potential window of -0.4 to $+0.8 \mathrm{~V}$, suggesting that these complexes do not directly generate ROS due to the $\mathrm{Au}(\mathrm{I}) / \mathrm{Au}(\mathrm{III})$ process but rather as a consequence of inhibition of TrxR [48]. This inhibition damages the thioredoxin system, an important cellular antioxidant defense, increasing ROS levels, and leading to cell death [51-53]. The apoptotic cell death produced by complexes $\mathbf{1}$ and $\mathbf{2}$ seems to be mediated by two mechanisms, both caspase-dependent and caspase-independent. This dual behavior has been reported for other gold complexes [49] and could be related to the increase in ROS levels produced by compounds. Elevated ROS causes mitochondrial membrane depolarization, which produces a disruption of the electron transport chain, leading to the release of cytochrome $\mathrm{c}$ and the apoptosis-inducing factor (AIF) from the mitochondria. Cytochrome c release induces caspase-dependent apoptosis, mediated by caspase- 3 and caspase- 9 activation, whilst AIF is translocated to the nucleus and produces caspase-independent apoptosis [48].

\section{Materials and Methods}

\subsection{Materials}

Triphenylphosphinegold(I) chloride (99.9\%, Strem Chemicals), Triethylphosphinegold(I) chloride (99\%, ABCR) and 2-(2'-pyridyl)benzimidazole (Hpben; 99.8\%, Aldrich, Darmstadt, Germany) were used as supplied.

\subsection{Physical Measurements}

Elemental analyses of $\mathrm{C}, \mathrm{H}$, and $\mathrm{N}$ were performed on a Carlo Erba EA-1108 (CE Instruments, Wigan, UK). IR spectra were recorded as KBr discs on a Bio-Rad FTS135 spectrophotometer (Bio-Rad Laboratories, Hercules, CA, USA) in the range $4000-400 \mathrm{~cm}^{-1}$. IR data are reported in the experimental section following abbreviations: vs = very strong; $\mathrm{s}=$ strong; $\mathrm{m}=$ medium; $\mathrm{w}=$ weak; $\mathrm{sh}=$ shoulder; $\mathrm{br}=$ broad .

${ }^{1} \mathrm{H}$ NMR and ${ }^{13} \mathrm{C}$ NMR spectra were recorded on a Bruker AC-300 spectrometer (Bruker BioSpin, Rheinstetten, Germany) at $296 \mathrm{~K}$ using DMF- $\mathrm{d}_{7}$ or $\mathrm{CDCl}_{3}$ as deuterated solvents. ${ }^{1} \mathrm{H}$ NMR and ${ }^{13} \mathrm{C}$ NMR were recorded in $\delta$ units relative to deuterated solvent as an internal reference. ${ }^{31} \mathrm{P}$ NMR spectra were recorded in $\mathrm{CDCl}_{3}$ at $202.46 \mathrm{MHZ}$ on a Bruker AMX 500 spectrometer (Bruker Analytik, Karlsruhe, Germany) using 5 mm o.d. tubes and are reported to external $\mathrm{H}_{3} \mathrm{PO}_{4}(85 \%)$. The following abbreviations were used as s = singlet; $\mathrm{d}=$ doublet; $\mathrm{t}=$ triplet; $\mathrm{m}=$ multiplet.

Positive electrospray ionization (ESI) mass spectra of the ligands and complexes were recorded on a LC-MSD 1100 Hewlett-Packard instrument (Hewlett-Packard, Palo Alto, CA, USA) (positive-ion mode, $98: 2 \mathrm{CH}_{3} \mathrm{OH} / \mathrm{HCOOH}$ as the mobile phase, $30-100 \mathrm{~V}$ ). Electronic spectra were recorded on a Cary50 spectrometer.

Electrochemical measurements were performed using an Autolab PGSTAT101 (Metrohm Autolab, Kanaalweg, The Netherlands) using a three-electrode configuration. The working electrode was a Metrohm model 6.1204.300 graphite disc, while a Pt wire and an $\mathrm{Ag} / \mathrm{AgCl}$ electrode served as counter and reference electrodes, respectively. Measurements were made with ca. $10^{-3} \mathrm{M}$ solutions of complexes in DMF using $0.1 \mathrm{M}$ tetraethylammonium perchlorate as a supporting electrolyte. 


\subsection{Synthesis of the Complexes}

Complexes were prepared through ligand deprotonation with sodium hydroxide, previous to the addition of the gold salt in stoichiometric relation [28,35]. Experimental procedure and characterization data for $\mathbf{1}$ and $\mathbf{2}$ are collected below.

\subsection{1. $\left(\mathrm{Au}(\mathrm{pben})\left(\mathrm{PPh}_{3}\right)\right)(\mathbf{1})$}

To a stirred solution of $\left(\mathrm{AuCl}\left(\mathrm{PPh}_{3}\right)\right)(200 \mathrm{mg}, 0.4 \mathrm{mmol})$ in methanol $(10 \mathrm{~mL})$ was added a methanolic solution $(4 \mathrm{~mL}$ ) of 2-(2'-pyridyl)benzimidazole (Hpben, $79 \mathrm{mg}, 0.4 \mathrm{mmol})$ and $\mathrm{NaOH}(16 \mathrm{mg}, 0.4 \mathrm{mmol})$. The yellow solution formed was stirred in absence of light for $24 \mathrm{~h}$ at room temperature. The crystalline white solid formed was filtered, washed with cold methanol, and dried under vacuum. Yield: $83 \%$. M.P.: $158-160{ }^{\circ} \mathrm{C}$. Anal Calcd. (\%) for $\mathrm{C}_{30} \mathrm{H}_{23} \mathrm{~N}_{3} \mathrm{PAu}\left(653.46 \mathrm{~g} \mathrm{~mol}^{-1}\right)$ : $\mathrm{C}, 55.1 ; \mathrm{N}, 6.4 ; \mathrm{H}, 3.6$. Found: $\mathrm{C}, 55.0 ; \mathrm{N}, 6.4$; H, 3.7. MS ES $(m / z) 654.14\left(\mathrm{Au}(\mathrm{pben})\left(\mathrm{PPh}_{3}\right)\right)^{+}$. IR $\left(\mathrm{KBr}, \mathrm{cm}^{-1}\right): v(\mathrm{C}-\mathrm{H}) 3050 \mathrm{w} ; v\left(\mathrm{PPh}_{3}\right)$ $1590 \mathrm{~m}, 1500 \mathrm{~m}, 1420 \mathrm{~s} ; 1230 \mathrm{~m}, 1160 \mathrm{~m}, 1045 \mathrm{~m}, 820 \mathrm{~m}$. UV-vis (DMSO): $\lambda_{\max }: 313,325 \mathrm{~nm}$. ${ }^{1} \mathrm{H}$ NMR $\left(\mathrm{CDCl}_{3}, \mathrm{ppm}\right): \delta 8.57\left(\mathrm{~d}, 1 \mathrm{H}, \mathrm{H}^{\prime}\right), 8.20\left(\mathrm{~d}, 1 \mathrm{H}, \mathrm{H}^{\prime}\right), 7.5-7.9(\mathrm{~m}+\mathrm{m}+\mathrm{m}, 4 \mathrm{H}$, $\mathrm{H}^{\prime}$-H7-H4-H4'), 7.5-7.7 (m + m + m, 15H, $\left.\mathrm{PPh}_{3}\right), 7.20$ (m, 2H, H5-H6). ${ }^{31} \mathrm{P} \mathrm{NMR}^{\prime}\left(\mathrm{CDCl}_{3}\right.$, ppm) 30.93 (s). $\mathrm{E}_{\text {ox }}\left(\right.$ at $\left.0.02 \mathrm{~V} \mathrm{~s}^{-1}\right)=-0.594 \mathrm{~V} ; \mathrm{E}_{\text {red }}\left(\right.$ at $\left.0.02 \mathrm{~V} \mathrm{~s}^{-1}\right)=-0.782 \mathrm{~V}$.

\subsection{2. $\left(\mathrm{Au}(\mathrm{pben})\left(\mathrm{PEt}_{3}\right)\right)(2)$}

A solution of Hpben $(83.5 \mathrm{mg}, 0.428 \mathrm{mmol})$ and $\mathrm{NaOH}(17.1 \mathrm{mg}, 0.428 \mathrm{mmol})$ in methanol $(4.3 \mathrm{~mL})$ was added to a stirred solution of $\left(\mathrm{AuCl}\left(\mathrm{PEt}_{3}\right)\right)(150 \mathrm{mg}, 0.428 \mathrm{mmol})$ in methanol $(3 \mathrm{~mL})$. The resulting mixture was stirred in the dark for $48 \mathrm{~h}$ at room temperature. Afterward, the solution was cooled to $4{ }^{\circ} \mathrm{C}$, the solvent was evaporated under vacuum, the oil formed was dissolved in acetonitrile, filtered, and the solvent removed under vacuum. The white solid formed was dried under vacuum. Yield: $56 \%$. M. P.: $156-158{ }^{\circ} \mathrm{C}$. Anal Calcd. (\%) for $\mathrm{C}_{18} \mathrm{H}_{23} \mathrm{~N}_{3} \mathrm{PAu}\left(509.33 \mathrm{~g} \mathrm{~mol}^{-1}\right)$ : C, 42.5; N, 8.3; H, 4.5. Found: C, 42.2; $\mathrm{N}, 8.1 ; \mathrm{H}, 4.6$. MS ES (m/z) $510.13\left(\mathrm{Au}(\mathrm{pben})\left(\mathrm{PEt}_{3}\right)\right)^{+}$. IR $\left(\mathrm{KBr}, \mathrm{cm}^{-1}\right): 3049 \mathrm{w}, \mathrm{v}(\mathrm{C}-\mathrm{H})$; $v\left(\mathrm{PEt}_{3}\right), 1587 \mathrm{~m}, 1499 \mathrm{w}, 1420 \mathrm{~s} ; 1275 \mathrm{~m}, 1140 \mathrm{~m}, 1044 \mathrm{~m}, 993 \mathrm{~m}, 820 \mathrm{~m}$. UV-vis (DMSO): $\lambda_{\text {max }}: 313 \mathrm{~nm} .{ }^{1} \mathrm{H}$ NMR $\left(\mathrm{CDCl}_{3}, \mathrm{ppm}\right): \delta 8.52\left(\mathrm{~d}, 1 \mathrm{H}, \mathrm{H6}^{\prime}\right), 8.47\left(\mathrm{~d}, 1 \mathrm{H}, \mathrm{H}^{\prime}\right), 7.65-7.85(\mathrm{~m}$, 3H, H7-H4-H4'), 7.23 (d, 1H, H5-H6), 1.31 (dt, 9H, PEt 3 ), 1-93 (m, 6H, PEt $).{ }^{31} \mathrm{P} \mathrm{NMR}^{2}$ $\left(\mathrm{CDCl}_{3}, \mathrm{ppm}\right) 26.91(\mathrm{~s}) . \mathrm{E}_{\mathrm{ox}}\left(\right.$ at $\left.0.02 \mathrm{~V} \mathrm{~s}^{-1}\right)=-0.597 \mathrm{~V} ; \mathrm{E}_{\text {red }}\left(\right.$ at $\left.0.02 \mathrm{~V} \mathrm{~s}^{-1}\right)=-0.811 \mathrm{~V}$. Recrystallization of 2 from acetonitrile afforded crystals suitable for X-ray crystallography.

\subsection{Cell Culture}

The human neuroblastoma SH-SY5Y cell line used in this study was purchased from the American Type Culture Collection (ATCC), number CRL2266. Cells were grown in Dulbecco's modified Eagle's medium: Nutrient Mix F-12 (DMEM/F-12) supplemented with $10 \%$ fetal bovine serum (FBS), $1 \%$ glutaMAX, $100 \mathrm{U} / \mathrm{mL}$ penicillin and $100 \mu \mathrm{g} / \mathrm{mL}$ streptomycin. Cells were maintained at $37^{\circ} \mathrm{C}$ in a humidified atmosphere of $5 \% \mathrm{CO}_{2}$ and $95 \%$ air. Cells were dissociated weekly using $0.05 \%$ trypsin/EDTA when they reached a confluence of $80 \%$. All reagents were provided by Thermo Fisher Scientific (Waltham, MA, USA).

\subsection{Cytotoxic Effects}

SH-SY5Y cells were seeded into 96-well plates at a density of $5 \times 10^{4}$ cells per well and allowed to grow for $24 \mathrm{~h}$. Cells were treated with compounds 1 and 2 at different concentrations $(0.01,0.1,0.5,1,2.5,5,7.5$, and $10 \mu \mathrm{M})$ for 6 and $24 \mathrm{~h}$. The cytotoxic effect of compounds was evaluated with MTT (3-(4,5-dimethyl thiazol-2-yl)-2,5-diphenyl tetrazolium bromide) assay [54-56]. SH-SY5Y cells were rinsed with saline solution and $200 \mu \mathrm{L}$ of $500 \mu \mathrm{g} / \mathrm{mL}$ MTT (Merck, Darmstadt, Germany) dissolved in saline buffer were added to each well. Following $1 \mathrm{~h}$ of incubation in an orbital shaker at $37^{\circ} \mathrm{C}$ and $300 \mathrm{rpm}$, SH-SY5Y cells were disaggregated with $5 \%$ sodium dodecyl sulfate. The absorbance of formazan crystals was measured at $595 \mathrm{~nm}$ with a spectrophotometer plate reader. Saponin at $1 \mathrm{mg} / \mathrm{mL}$ was used as cell death control. The concentration of compound that produced 
a $50 \%$ inhibition of cell survival (half maximal inhibitory concentration, $\mathrm{IC}_{50}$ ) was determined by fitting the data with a $\log$ (inhibitor) vs response model using GraphPad Prism 6 software.

\subsection{Flow Cytometry Analysis of Cell Death Type}

The cell death type induced by compounds was determined with an Annexin VFITC Apoptosis detection kit (Immunostep, Salamanca, Spain) following the manufacturer's instructions [56]. Cells were seeded in 12-well plates at $1 \times 10^{6}$ cells per well and treated with compounds at $\mathrm{IC}_{50}$ concentrations for 6 and $24 \mathrm{~h}$. Then, cells were washed, resuspended in PBS (Phophate-Buffered Saline), and $5 \mu \mathrm{L}$ of Annexin V-FITC and Propidium Iodide (PI) were added to each tube. Cells were incubated for $15 \mathrm{~min}$ in the dark and analyzed by flow cytometry using the ImageStreamMKII instrument (Amnis Corporation, LuminexCorp, Austin, TX, USA). The fluorescence of 10,000 events was analyzed with IDEAS Application 6.0 software (Amnis Corporation, LuminexCorp). The percentages of apoptotic cells, including early apoptotic cells (Annexin-FITC positive and PI negative) and late apoptotic cells (Annexin-FITC and PI-positive), and necrotic cells (Annexin-FITCnegative and PI-positive), were calculated. To further confirm if apoptotic cell death was occurring, SH-SY5Y cells were preincubated with the pan-caspase inhibitor Z-VAD-FMK (Merck) for $24 \mathrm{~h}$. Then, the assay was carried out as described above. Staurosporine (STS) (Merck) was used as a positive control in all the experiments [56].

\subsection{Caspase-3 Assay}

Analysis of caspase-3 activity in SH-SY5Y cells after exposure to gold complexes was carried out using the EnzChek Caspase-3 Assay Kit (Thermo Fisher Scientific), following the manufacturer's instructions [56]. Cells were seeded in 12-well plates at $1 \times 10^{6}$ cells per well and treated with compounds at IC50 concentrations for 6 and $24 \mathrm{~h}$. Then, cells were lysed with $50 \mu \mathrm{L}$ lysis buffer $(10 \mathrm{mM}$ TRIS, pH 7.5, $0.1 \mathrm{M} \mathrm{NaCl}, 0.01 \%$ CHAPS (3-[(3-chloramidopropyl)dimethylammonio]-1-propanesulfonate), $1 \mathrm{mM}$ EDTA and 0.01\% TRITON $\left.^{\text {TM }} \mathrm{X}-100\right)$, resuspended and centrifuged. The pellet was resuspended in $50 \mu \mathrm{L}$ of reaction buffer (20 mM PIPES, pH 7.4, 4 mM EDTA, $0.2 \%$ CHAPS), $10 \mu \mathrm{L}$ of 1 M DTT (dithiothreitol), and $590 \mu \mathrm{L}$ of $\mathrm{H}_{2} \mathrm{O}$. Then, $20 \mu \mathrm{L}$ of $0.2 \mathrm{mM}$ Z-DEVD-AMC substrate (7-amino-4-methylcoumarin-derived substrate) were added, and lysates were incubated for $30 \mathrm{~min}$ at room temperature. Finally, the fluorescence was monitored with a spectrophotometer plate reader (excitation/emission 342/441 nm). Signals were normalized by protein concentration, which was quantified by the Bradford method. Briefly, $2 \mu \mathrm{L}$ of each lysate were added to $200 \mu \mathrm{L}$ of Bradford reagent, and absorbance was measured at $590 \mathrm{~nm}$. Protein concentration in samples was determined using a standard curve with known concentrations of bovine serum albumin. Experiments were carried out three times in triplicate, and STS was used as a positive control.

\subsection{Determination of ROS Production}

Intracellular ROS production was evaluated with the fluorescent dye carboxy- $\mathrm{H}_{2} \mathrm{DCF}$ DA [57]. Cells were treated with complexes 1 and 2 at concentrations between 0.01 and $10 \mu \mathrm{M}$ for $24 \mathrm{~h}$. After this time, cells were washed with medium without serum, and $20 \mu \mathrm{M}$ carboxy- $\mathrm{H}_{2}$ DCFDA was added. The plate was incubated in an orbital shaker for $1 \mathrm{~h}$ at $37^{\circ} \mathrm{C}$ and $300 \mathrm{rpm}$. Then, PBS was added to each well, and cells were incubated for $30 \mathrm{~min}$ before measuring the fluorescence with a spectrophotometer plate reader $(495 \mathrm{~nm}$ excitation and $527 \mathrm{~nm}$ emission). Experiments were performed at least three times by triplicate. The known oxidant tert-butyl hydroperoxide (TBHP) at $75 \mu \mathrm{M}$ was used as a positive control to validate the assay.

\subsection{Statistical Analysis}

Data are presented as mean \pm SEM. Statistical differences were evaluated by Student's t-test with Graph Pad Prism 6 software. Statistical significance was considered at $p<0.05$. 


\subsection{Crystallographic Studies}

Crystals $\mathbf{1}$ and $\mathbf{2}$ were obtained as mentioned above. Data for $\mathbf{1}$ and $\mathbf{2}$ were collected at $293 \mathrm{~K}$ for $\mathbf{1}$ and $100 \mathrm{~K}$ for $\mathbf{2}$ on a BRUKER CCD Smart diffractometer, using graphitemonochromated Mo-K $\alpha$ radiation $(\mathrm{k}=0.71073 \AA)$ and corrected for absorption effects by SADABS [58]. The structures were solved by the Patterson method [59], and successive Fourier synthesis gave the location of heavy atoms. All hydrogen atoms were included in the model at geometrically calculated positions and refined on $\mathrm{F}^{2}$. Diffuse scattering reflections due to the disordered methanol solvent molecules in $\mathbf{1}$ were corrected by SQUEEZE [39]. One of the $\mathrm{PEt}_{3}$ groups present in the structure of 2 also presents disorder, which was modeled considering two alternative positions (occupancy factors of 64 and 36\%) for the Et groups and using common anisotropic factors for both carbon atoms. Atomic scattering factors were taken from International Tables for X-ray crystallography [60].

Molecular graphics were generated by ORTEPIII [61] and MERCURY [62]. Crystal and structure refinement data are reported in Table 4.

Table 4. Crystal data and structure refinement for $\mathbf{1}$ and $\mathbf{2}$.

\begin{tabular}{|c|c|c|}
\hline Compound & 1 & 2 \\
\hline Empirical formula & $\mathrm{C}_{30} \mathrm{H}_{23} \mathrm{AuN}_{3} \mathrm{P}$ & $\mathrm{C}_{18} \mathrm{H}_{23} \mathrm{AuN}_{3} \mathrm{P}$ \\
\hline Formula weight & 653.45 & 509.33 \\
\hline Temperature (K) & 293(2) & $100(2)$ \\
\hline Wavelength $(\AA)$ & 0.71073 & 0.71073 \\
\hline Crystal system & Monoclinic & Monoclinic \\
\hline Space group & $\mathrm{P} 21 / \mathrm{c}$ & $\mathrm{P} 21 / \mathrm{n}$ \\
\hline a $(\AA)$ & $9.4636(5)$ & $14.6206(10)$ \\
\hline $\mathrm{b}(\AA)$ & $18.3327(10)$ & $13.0799(9)$ \\
\hline$c(\AA)$ & $32.0984(17)$ & $20.0179(14)$ \\
\hline$\alpha\left(^{\circ}\right)$ & 90 & 90 \\
\hline$\beta\left({ }^{\circ}\right)$ & $98.2780(10)$ & $102.335(2)^{\circ}$ \\
\hline$\gamma\left({ }^{\circ}\right)$ & 90 & 90 \\
\hline Volume $\left(\AA^{3}\right)$ & $5510.8(5)$ & $3739.8(4)$ \\
\hline $\mathrm{Z}$ & 8 & 8 \\
\hline Density (calculated) $\left(\mathrm{g} \mathrm{cm}^{-3}\right)$ & 1.575 & 1.809 \\
\hline Absorption coefficient $\left(\mathrm{mm}^{-1}\right)$ & 5.419 & 7.956 \\
\hline $\mathrm{F}(000)$ & 2544 & 1968 \\
\hline Crystal size $\left(\mathrm{mm}^{3}\right)$ & $0.35 \times 0.15 \times 0.09$ & $0.311 \times 0.281 \times 0.252$ \\
\hline Theta range for data collection $\left(^{\circ}\right)$ & 1.70 to 28.01 & 2.485 to 28.423 \\
\hline Index ranges & $\begin{array}{l}-12 \leq \mathrm{h} \leq 12 \\
-17 \leq \mathrm{k} \leq 24 \\
-39 \leq 1 \leq 42\end{array}$ & $\begin{array}{l}-19 \leq \mathrm{h} \leq 19 \\
-17 \leq \mathrm{k} \leq 17 \\
-25 \leq 1 \leq 26\end{array}$ \\
\hline Reflections collected & 30301 & $8 \overline{9} 059$ \\
\hline Independent reflections & 12296 & 9338 \\
\hline Data/restraints/parameters & $12296 / 0 / 631$ & $9338 / 10 / 444$ \\
\hline Goodness-of-fit on $\mathrm{F}^{2}$ & 0.805 & 1.140 \\
\hline Largest diff. peak and hole (e $\AA^{-3}$ ) & 1.345 and -1.339 & 4.100 and -5.096 \\
\hline Final R indices (I>2sigma(I)) & $\mathrm{R} 1=0.0440, \mathrm{w} R 2=0.0875$ & $R 1=0.0463, \mathrm{w} R 2=0.0881$ \\
\hline $\mathrm{R}$ indices (all data) & $\mathrm{R} 1=0.1218, \mathrm{w} R 2=0.0979$ & $R 1=0.0640, \mathrm{w} R 2=0.0997$ \\
\hline
\end{tabular}

\section{Conclusions}

Two new gold(I) complexes containing benzimidazole and two different phosphines have been prepared and characterized. The complex that incorporates triethylphosphine ligand (2) is more cytotoxic against neuroblastoma SH-SY5Y cells than the complex with triphenylphosphine ligand (1). Our studies show that complexes $\mathbf{1}$ and $\mathbf{2}$ induce apoptosis through both caspase-dependent and caspase-independent mechanisms. In the seek of novel anticancer agents through different mechanisms than cisplatin or other $\mathrm{Pt}(\mathrm{II}) / \mathrm{Pd}(\mathrm{II})$ compounds, the pro-apoptotic effects of complexes $\mathbf{1}$ and $\mathbf{2}$ in neuroblastoma cells make them promising molecules for further anticancer studies. 
Supplementary Materials: The following are available online at https:/ /www.mdpi.com/1424-824 7/14/1/10/s1, Figure S1: ESI MS spectrum for 1; Figure S2: ESI MS spectrum for 2; Figure S3: UV-Vis spectrum for 1; Figure S4: UV-Vis spectrum for 2; Figure S5: IR spectrum for 1; Figure S6: IR spectrum for 2; Figure S7: ${ }^{1} \mathrm{H}$ NMR spectrum for 1 (registered in $\mathrm{CDCl}_{3}$ ). Inset: details zoom to 7-9 ppm; Figure S8: ${ }^{1} \mathrm{H}$ NMR spectrum for 2 (registered in $\mathrm{CDCl}_{3}$ ); Figure S9: ${ }^{1} \mathrm{H}$ NMR spectrum for Hpben. Inset: details zoom to 7-9 ppm; Figure S10: ${ }^{13} \mathrm{C}$ NMR spectrum for Hpben; Figure S11: Heteronuclear Multiple Quantum Coherence (HMQC) correlation for Hpben; Figure S12: Heteronuclear Multiple Bond Correlation (HMBC) for Hpben; Figure S13: ${ }^{13} \mathrm{C}$ NMR spectrum for 1 (registered in $\mathrm{CDCl}_{3}$ ); Figure S14: ${ }^{31} \mathrm{P}$ NMR spectrum for 1 (registered in $\mathrm{CDCl}_{3}$ ); Figure S15: ${ }^{13} \mathrm{C} \mathrm{NMR}$ spectrum for 2 (registered in $\mathrm{CDCl}_{3}$ ); Figure S16: ${ }^{31} \mathrm{P} \mathrm{NMR}$ spectrum for 2 (registered in $\mathrm{CDCl}_{3}$ ); Figure S17: MERCURY view for 1; Figure S18: MERCURY view for 2; Figure S19: Cytotoxicity curves for 1 and 2; Checkcif files for the crystal structures of $\mathbf{1}$ and $\mathbf{2}$.

Author Contributions: Conceptualization, Á.S.-G. and M.M.; methodology, L.R., Á.S.-G., R.A., and M.M.; validation, Á.S.-G., R.A., A.A., and M.M.; formal analysis, L.R., R.A., E.M.V.-L., E.G.-M.; investigation, L.R., Á.S.-G., R.A., and M.M.; data curation, L.R., Á.S.-G., R.A., E.M.V.-L., and E.G.-M.; writing-original draft preparation, L.R., R.A., and M.M.; writing-review and editing, L.R., Á.S.-G., R.A., A.A., E.M.V.-L., M.M.; supervision, Á.S.-G., R.A., A.A., and M.M.; project administration, M.M. funding acquisition, A.A. and M.M. All authors have read and agreed to the published version of the manuscript.

Funding: The research leading to these results has received funding from the following FEDER cofunded-grants. From Consellería de Cultura, Educación e Ordenación Universitaria, Xunta de Galicia, 2017 GRC GI-1682 (ED431C 2017/01), 2018 GRC GI-1584 (ED431C 2018/13), MetalBIO Network (ED431D 2017/01). From CDTI (Centro para el Desarrollo Técnico Industrial) and Technological Funds, supported by Ministerio de Economía, Industria y Competitividad, CTQ2015-65707-C22-P, AGL2016-78728-R (AEI/FEDER, UE), ISCIII/PI16/01830 and RTC-2016-5507-2, ITC-20161072. From European Union POCTEP 0161-Nanoeaters -1-E-1, Interreg AlertoxNet EAPA-317-2016, Interreg Agritox EAPA-998-2018, and H2020 778069-EMERTOX.

Institutional Review Board Statement: Not applicable.

Informed Consent Statement: Not applicable.

Data Availability Statement: Data is contained within the article or supplementary material.

Conflicts of Interest: The authors declare no conflict of interest. The funders had no role in the design of the study; in the collection, analyses, or interpretation of data; in the writing of the manuscript, or in the decision to publish the results.

\section{References}

1. Casini, A.; Sun, R.W.; Ott, I. Medicinal chemistry of gold anticancer metallodrugs. Metallo-Drugs: Development and Action of Anticancer Agents. Met. Ions Life Sci. 2018, 18, 199-218.

2. Dabrowiak, J.C. Metal Complexes for Treating Arthritis and Diabetes. In Metals in Medicine, 2nd ed.; John Wiley \& Sons Ltd.: Hoboken, NJ, USA, 2017; pp. 245-263.

3. Sutton, B.M. Gold compounds for rheumatoid arthritis. Gold Bull. 1986, 19, 15-16. [CrossRef]

4. Messori, L.; Marcon, G. Gold Complexes in the Treatment of. In Metal Ions in Biological Systems: Volume 41: Metal Ions and Their Complexes in Medication; CRC Press: Boca Raton, FL, USA, 2004; pp. 279-304.

5. Berners-Price, S.J.; Filipovska, A. Gold compounds as therapeutic agents for human diseases. Metallomics $2011,3,863-873$. [CrossRef]

6. Madeira, J.M.; Renschler, C.J.; Mueller, B.; Hashioka, S.; Gibson, D.L.; Klegeris, A. Novel protective properties of auranofin: Inhibition of human astrocyte cytotoxic secretions and direct neuroprotection. Life Sci. 2013, 92, 1072-1080. [CrossRef]

7. Roder, C.; Thomson, M.J. Auranofin: Repurposing an old drug for a golden new age. Drugs RED 2015, 15, 13-20. [CrossRef]

8. Rothan, H.A.; Stone, S.; Natekar, J.; Kumari, P.; Arora, K.; Kumar, M. The FDA-approved gold drug auranofin inhibits novel coronavirus (SARS-COV-2) replication and attenuates inflammation in human cells. Virology 2020, 547, 7-11. [CrossRef]

9. Mirzadeh, N.; Reddy, T.S.; Bhargava, S.K. Advances in diphosphine ligand-containing gold complexes as anticancer agents. Coord. Chem. Rev. 2019, 388, 343-359. [CrossRef]

10. Mora, M.; Gimeno, M.C.; Visbal, R. Recent advances in gold-NHC complexes with biological properties. Chem. Soc. Rev. 2019, 48, 447-462. [CrossRef]

11. Iacopetta, D.; Rosano, C.; Sirignano, M.; Mariconda, A.; Ceramella, J.; Ponassi, M.; Saturnino, C.; Sinicropi, M.S.; Longo, P. Is the way to fight cancer paved with gold? Metal-based carbene complexes with multiple and fascinating biological features. Pharmaceuticals 2020, 13, 91. [CrossRef] 
12. Marzo, T.; Massai, L.; Pratesi, A.; Stefanini, M.; Cirri, D.; Magherini, F. Replacement of the Thiosugar of Auranofin with Iodide Enhances the Anticancer Potency in a Mouse Model of Ovarian Cancer. ACS Med. Chem. Lett. 2019, 10, 656-660. [CrossRef]

13. Marzo, T.; Cirri, D.; Gabbiani, C.; Gamberi, T.; Magherini, F.; Pratesi, A. Auranofin, Et3PAuCl, and Et3PAuI Are Highly Cytotoxic on Colorectal Cancer Cells: A Chemical and Biological Study. ACS Med. Chem. Lett. 2017, 8, 997-1001. [CrossRef] [PubMed]

14. Gonzalez-Barcia, L.M.; Fernandez-Fariña, S.; Rodríguez-Silva, L.; Bermejo, M.R.; González-Noya, A.M.; Pedrido, R. Comparative study of the antitumoral activity of phosphine-thiosemicarbazone gold(I) complexes obtained by different methodologies. J. Inorg. Biochem. 2020, 203, 110931. [CrossRef] [PubMed]

15. Yoo, M.-H.; Xu, X.-M.; Carlson, B.A.; Gladyshev, V.N.; Hatfield, D.L. Thioredoxin reductase 1 deficiency reverses tumor phenotype and tumorigenicity of lung carcinoma cells. J. Biol. Chem. 2006, 281, 13005-13008. [CrossRef] [PubMed]

16. Casini, A.; Hartinger, C.; Gabbiani, C.; Mini, E.; Dyson, P.J.; Keppler, B.K.; Messori, L. Gold (III) compounds as anticancer agents: Relevance of gold-protein interactions for their mechanism of action. J. Inorg. Biochem. 2008, 102, 564-575. [CrossRef] [PubMed]

17. Nobili, S.; Mini, E.; Landini, I.; Gabbiani, C.; Casini, A.; Messori, L. Gold compounds as anticancer agents: Chemistry, cellular pharmacology, and preclinical studies. Med. Res. Rev. 2010, 30, 550-580. [CrossRef]

18. Ott, I. On the medicinal chemistry of gold complexes as anticancer drugs. J. Coord. Chem. Rev. 2009, 253, 1670-1681. [CrossRef]

19. Hassan, F.; Al-Aridhi, D.T. Antitumor effect of 4-(N, N-dimethyl)-3-(3-Mercapto-5-Phenyl [1,2,4] triazol-4yl)-thiazolidin-4-one in liver carcinoma cell lines Hep G2 by (HCS) technique. Int. J. Pharm. Sci. 2015, 5, 1317-1322.

20. Zhong, L.; Arnér, E.S.J.; Holmgren, A. Targeting thioredoxin reductase is a basis for cancer therapy by arsenic trioxide. Proc. Natl. Acad. Sci. USA 2007, 104, 12288-12293.

21. Zhang, X.; Frezza, M.; Milacic, V.; Ronconi, L.; Fan, Y.; Bi, C.; Fregona, D.; Dou, Q.P. Inhibition of tumor proteasome activity by gold-dithiocarbamato complexes via both redox-dependent and -independent processes. J. Cell. Biochem. 2010, 109, 162-172. [CrossRef]

22. Barnard, P.; Berners-Price, S.J. Targeting the mitochondrial cell death pathway with gold compounds. Coord. Chem. Rev. 2007, 251, 1889-1902. [CrossRef]

23. González-Barcia, L.M.; Romero, M.J.; González-Noya, A.M.; Bermejo, M.R.; Maneiro, M.; Zaragoza, G.; Pedrido, R. “The Golden Method": Electrochemical synthesis is an efficient route to gold complexes. Inorg. Chem. 2016, 55, 7823-7825. [CrossRef] [PubMed]

24. Rodríguez-Fanjul, V.; López-Torres, E.; Mendiola, M.A.; Pizarro, A.M. Gold (III) bis (thiosemicarbazonate) compounds in breast cancer cells: Cytotoxicity and thioredoxin reductase targeting. Eur. J. Med. Chem. 2018, 148, 372-383. [CrossRef]

25. Ortego, L.; Cardoso, F.; Manrins, S.; Fillat, M.F.; Laguna, A.; Meireles, M.; Villacampa, M.D.; Gimeno, M.C. Strong inhibition of thioredoxin reductase by highly cytotoxic gold (I) complexes. DNA binding studies. J. Inorg. Biochem. 2014, 130, 32-37. [CrossRef]

26. Serebryanskaya, T.V.; Lyakhov, A.S.; Ivashkevich, L.S.; Schur, J.; Frias, C.; Prokop, L. Gold (I) thiotetrazolates as thioredoxin reductase inhibitors and antiproliferative agents. Dalton Trans. 2015, 44, 1161-1169. [CrossRef]

27. Saggioro, D.; Rigobello, M.P.; Paloschi, L.; Folda, A.; Moggach, S.A.; Parsons, S.; Ronconi, L.; Fregona, D.; Bindoli, A. Gold (III)-dithiocarbamato complexes induce cancer cell death triggered by thioredoxin redox system inhibition and activation of ERK pathway. Chem. Biol. 2007, 14, 1128-1139. [CrossRef]

28. Barreiro, E.; Casas, J.S.; Couce, M.D.; Sánchez, A.; Sánchez-González, A.; Sordo, J.; Vázquez-López, E. Mono and dinuclear phosphinegold(I) sulfanylcarboxylates: Influence of nuclearity and substitution of PPh3 for Pet3 on cytotoxicity. J. Inorg. Biochem. 2014, 138, 89-98. [CrossRef]

29. Bian, M.; Fan, R.; Jiang, G.; Wang, Y.; Lu, Y.; Liu, W. Halo and pseudohalo gold(I)-NHC complexes derived from 4,5diarylimidazoles with excellent in vitro and in vivo anticancer activities against HCC. J. Med. Chem. 2020, 63, 9197-9211. [CrossRef]

30. Meyer, A.; Oehninger, L.; Geldmacher, Y.; Alborzinia, H.; Wölfl, S.; Sheldrick, W.S.; Ott, I. Gold(I) N-heterocyclic carbene complexes with naphthalimide ligands as combined thioredoxin reductase inhibitors and DNA intercalators. ChemMedChem 2014, 9, 1794-1800. [CrossRef] [PubMed]

31. Terrón, A.; Buils, J.; Mooibroek, T.J.; Barceló-Oliver, M.; García-Raso, A.; Fiol, J.J.; Frontera, A. Synthesis, X-ray characterization and regium bonding interactions of a trichlorido(1-hexylcytosine)gold(III) complex. Chem. Commun. 2020, 56, 3524-3527. [CrossRef]

32. Casini, A.; Cinellu, M.A.; Minghetti, G.; Gabbiani, C.; Coronnello, M.; Mini, E.; Messori, L. Structural and solution chemistry, antiproliferative effects, and DNA and protein binding properties of a series of dinuclear gold(III) compounds with bypyridyl ligands. J. Med. Chem. 2006, 49, 5524-5531. [CrossRef] [PubMed]

33. Olsen, P.M.; Ruiz, C.; Lussier, D.; Le, B.K.; Angel, N.; Smith, M.; Hwang, C.; Khatib, R.; Jenkins, J.; Adams, K.; et al. Synthesis, characterization, and antitumor activity of unusual pseudo five coordinate gold(III) complexes: Distinct cytotoxic mechanism or expensive ligand delivery systems? J. Inorg. Biochem. 2014, 141, 121-131. [CrossRef] [PubMed]

34. Serratrice, M.; Cinellu, M.A.; Maiore, L.; Pilo, M.; Zucca, A.; Gabbiani, C.; Guerri, A.; Landini, I.; Nobili, S.; Mini, E.; et al. Synthesis, structural characterization, solution behavior, and in vitro antiproliferative properties of a series of gold complexes with 2-(2'-pyridyl)benzimidazole as ligand: Comparisons of gold(III) versus gold(I) and mononuclear versus binuclear derivatives. Inorg. Chem. 2012, 51, 3161-3171. [CrossRef] [PubMed]

35. Maiore, L.; Aragoni, M.C.; Deiana, C.; Cinellu, M.A.; Isaia, F.; Lippolis, V.; Pintus, A.; Serratrice, M.; Arca, M. Structure-activity relationships in cytotoxic AuI/AuIII complexes derived from 2-(2'-pyridyl)benzimidazole. Inorg. Chem. 2014, 53, 4068-4080. [CrossRef] [PubMed] 
36. Serratrice, M.; Maiore, L.; Zucca, A.; Stoccoro, S.; Landini, I.; Mini, E.; Massai, L.; Ferraro, G.; Merlino, A.; Messori, L.; et al. Cytotoxic properties of a new organometallic platinum(II) complex and its gold(I) heterobimetallic derivatives. Dalton Trans. 2016, 45, 579-590. [CrossRef] [PubMed]

37. Jin, I.S.; Jo, M.J.; Park, C.-W.; Chung, Y.B.; Kim, J.-S.; Shin, D.H. Physicochemical, pharmacokinetic, and toxicity evaluation of Soluplus polymeric micelles encapsulating fenbendazole. Pharmaceutics 2020, 12, 1000. [CrossRef] [PubMed]

38. Vasava, M.S.; Bhoi, M.N.; Rathwa, S.K.; Jethava, D.J.; Acharya, P.T.; Patel, D.B.; Patel, H.D. Benzimidazole: A milestone in the field of medicinal chemistry. Mini-Rev. Med. Chem. 2020, 20, 532-565. [CrossRef] [PubMed]

39. Spek, A.L. PLATON, an Integrated Tool for the Analysis of the Results of a Single Crystal Structure Determination. Acta Crystallogr. 1990, 46, C34.

40. Munakata, M.; Yan, S.G.; Maekawa, M.; Akiyama, M.; Kitagawa, S. Solid and solution structures of ternary gold(I) complexes with triphenylphosphine and nitrogen-containing ligands. J. Chem. Soc. Dalton Trans. 1997, 4257-4262. [CrossRef]

41. Nomiya, K.; Noguchi, R.; Ohsawa, K.; Tsuela, K. Synthesis and crystal structure of gold(I) complexes with triazole and triphenylphosphine ligands: Monomeric complex $\left[\mathrm{Au}(1,2,3-\mathrm{L})\left(\mathrm{PPh}_{3}\right)\right]$ and dimeric complex $[\mathrm{Au}(1,2,4-\mathrm{L})(\mathrm{PPh} 3)] 2(\mathrm{HL}=$ triazole $)$ through an $\mathrm{Au}-\mathrm{Au}$ bond in the solid state. J. Chem. Soc. Dalton trans. 1998, 4101-4108. [CrossRef]

42. Barreiro, E.; Casas, J.S.; Couce, M.D.; Sánchez, A.; Sánchez-González, A.; Sordo, J. Dinuclear triphenylphosphinegold(I) sulfanylcarboxylates: Synthesis, structure and cytotoxic activity against cancer cell lines. J. Inorg. Biochem. 2010, 104, 551-559. [CrossRef]

43. Van Tonder, A.; Joubert, A.M.; Cromarty, A.D. Limitations of the 3-(4, 5-dimethylthiazol-2-yl)-2, 5-diphenyl-2H-tetrazolium bromide (MTT) assay when compared to three commonly used cell enumeration assays. BMC Res. Notes 2015, 8, 47. [CrossRef]

44. Scudiero, D.A.; Shoemaker, R.H.; Paull, K.D.; Monks, A.; Tierney, S.; Nofziger, T.H.; Boyd, M.R. Evaluation of a soluble tetrazolium/formazan assay for cell growth and drug sensitivity in culture using human and other tumor cell lines. Cancer Res. 1988, 48, 4827-4833.

45. Stepanenko, A.A.; Dmitrenko, V.V. Pitfalls of the MTT assay: Direct and off-target effects of inhibitors can result in over/underestimation of cell viability. Gene 2015, 574, 193-203. [CrossRef]

46. Belmokhtar, C.A.; Hillion, J.; Ségal-Bendirdjian, E. Staurosporine induces apoptosis through both caspase-dependent and caspase-independent mechanisms. Oncogene 2001, 20, 3354-3362. [CrossRef] [PubMed]

47. Déas, O.; Dumont, C.; MacFarlane, M.; Rouleau, M.; Hebib, C.; Harper, F.; Senik, A. Caspase-independent cell death induced by anti-CD2 or staurosporine in activated human peripheral T lymphocytes. J. Immunol. 1998, 161, 3375-3383.

48. Van Le, H.; Babak, M.V.; Ali Ehsan, M.; Altaf, M.; Reichert, L.; Gushchin, A.L.; Han Ang, W.; Isab, A.A. Highly cytotoxic gold(I)phosphane dithiocarbamate complexes trigger an ER stress-dependent immune response in ovarian cancer cells. Dalton Trans. 2020, 49, 7355-7363. [CrossRef]

49. Wang, Y.; He, Q.Y.; Sun, R.W.Y.; Che, C.M.; Chiu, J.F. Gold (III) porphyrin 1a induced apoptosis by mitochondrial death pathways related to reactive oxygen species. Cancer Res. 2005, 65, 11553-11564. [CrossRef] [PubMed]

50. Donzelli, E.; Carfi, M.; Miloso, M.; Strada, A.; Galbiati, S.; Bayssas, M.; Griffon-Etienne, G.; Cavaletti, G.; Petruccioli, M.G.; Tredici, G. Neurotoxicity of platinum compounds: Comparison of the effects of cisplatin and oxaliplatin on the human neuroblastoma cell line SH-SY5Y. J. Neurooncol. 2004, 67, 65-73. [CrossRef] [PubMed]

51. Bindoli, A.; Rigobello, M.P.; Scutari, G.; Gabbiani, C.; Casini, A.; Messori, L. Thioredoxin reductase: A target for gold compounds acting as potential anticancer drugs. Coord. Chem. Rev. 2009, 253, 1692-1707. [CrossRef]

52. Scalcon, V.; Bindoli, A.; Rigobello, M.P. Significance of the mitochondrial thioredoxin reductase in cancer cells: An update on role, targets and inhibitors. Free Rad. Biol. Med. 2018, 127, 62-79. [CrossRef]

53. You, B.R.; Park, W.H. Auranofin induces mesothelioma cell death through oxidative stress and GSH depletion. Oncol. Rep. 2016, 35, 546-551. [CrossRef] [PubMed]

54. McCord, J.M.; Fridovich, I. Superoxide dismutase an enzymic function for erythrocuprein (hemocuprein). J. Biol. Chem. 1969, 244, 6049-6055. [PubMed]

55. Vega-Avila, E.; Pugsley, M.K. An overview of colorimetric assay methods used to assess survival or proliferation of mammalian cells. Proc. West. Pharmacol. Soc. 2011, 54, 10-14.

56. Alvariño, R.; Alonso, E.; Bornancin, L.; Bonnard, I.; Inguimbert, N.; Banaigs, B.; Botana, L.M. Biological Activities of Cyclic and Acyclic B-Type Laxaphycins in SH-SY5Y Human Neuroblastoma Cells. Mar. Drugs 2020, 18, 364. [CrossRef]

57. Tetz, L.M.; Kamau, P.W.; Cheng, A.A.; Meeker, J.D.; Loch-Caruso, R. Troubleshooting the dichlorofluorescein assay to avoid artifacts in measurement of toxicant-stimulated cellular production of reactive oxidant species. J. Pharmacol. Toxicol. Methods 2013, 67, 56-60. [CrossRef] [PubMed]

58. Sheldrick, G.M. SADABS. Program for Absorption Correction; University of Göttingen: Göttingen, Germany, 1996.

59. Sheldrick, G.M. SHELX97. An Integrated System for Solving and Refining Crystal Structures from Diffraction Data; University of Göttingen: Göttingen, Germany, 1997.

60. Ibers, J.A.; Hamilton, W.C. (Eds.) International Tables for X-ray Crystallography; Kynoch Press: Birmingham, UK; Kluwer Academic Publishers: Dordrecht, The Netherlands, 1974; Volume IV.

61. Burnett, M.N.; Johnson, C.K. ORTEPIII, ORNL-6895; Oak Ridge National Laboratory: Oak Ridge, TN, USA, 1996.

62. Macrae, C.F.; Edgington, P.R.; McCabe, P.; Shields, G.P.; Taylor, R.; Towler, M.; van de Streek, J. Mercury: Visualization and analysis of crystal structures. J. Appl. Crystallogr. 2006, 39, 453-457. [CrossRef] 